\title{
Penentuan Harga Pokok Produk Bersama Pada Usaha Kecil Menengah
}

\author{
Ayu Rakhma Wuryandini' ${ }^{1}$, Lukman Pakaya ${ }^{2}$ \\ ${ }^{1,2}$ Jurusan Akuntansi, Fakultas Ekonomi, Universitas Negeri Gorontalo, Jl. Jend. Sudirman No. 6 \\ Kota Gorontalo, Gorontalo 96128, Indonesia \\ E-mail: ayurakma@ung.ac.id ${ }^{1}$, lukmanpakaya@ung.ac.id ${ }^{2}$
}

\begin{tabular}{ll}
\hline Article History: & Abstract: \\
Received: 02-11-2021 & Tidak sedikit UMK yang mengetahui tentang manfaat \\
Revised: 07-11-2021 & penentuan harga pokok produk bersama menghitung alokasi \\
Accepted: 08-11-2021 & biaya bersama ke tiap produk yang dihasilkan. Sehingga \\
& dalam kegiatan pengabdian ini pengabdi ingin memberikan \\
& pelatihan harga pokok produk sebagai dasar perhitungan \\
& alokasi biaya bersama ke tiap produk yang dihasilkan. \\
& Metode yang digunakan adalah metode nilai jual relatif. \\
& Hasil pengabdian menunjukkan bahwa pengusaha mikro \\
Kecil masih memerlukan pembinaan lebih lanjut terkait \\
Concept, Housewife & perhitungan Harga Pokok Produk bersama mengingat UMK \\
& Desa Botubarani sangat antusias dalam mengembangkan \\
& produknya lebih maju.
\end{tabular}

\section{Pendahuluan}

Dunia usaha Indonesia pada saat ini masih didominasi oleh Usaha Mikro Kecil (UMK). Dari hasil SE 2016-Lanjutan, jumlah usaha ini mencapai lebih dari 26 juta usaha atau 98,68 persen dari total usaha nonpertanian di Indonesia. Usaha ini mampu menyerap tenaga kerja Indonesia lebih dari 58 juta orang atau sekitar 75,33 persen dari total tenaga kerja nonpertanian. Ketika krisis menerpa kerja nonpertanian pada sekitar tahun 1997-1998, UMK terbukti tetap berdiri kokoh di saat usaha-usaha besar lainnya tidak sedikit yang berjatuhan (Statistik 2017).

Kelemahan yang dihadapi oleh para pengusaha UMKM dalam meningkatkan kemampuan usahanya sangat kompleks, mulai dari masalah permodalan, kurangnya kemampuan manajerial, operation skills menjalankan organisasi, pemasaran, persaingan dan kondisi perekonomian negara yang membuat UMKM memiliki keterbatasan ruang lingkup usahanya (Suci, Tinggi, and Ekonomi 2017) Tak bisa dipungkiri lagi saat ini Indonesia sudah menghadapi Masyarakat Ekonomi ASEAN (MEA) dengan kondisi sudah menghadapi pasar bebas. Harapan itu terletak pada peran pemerintah dengan upaya yang komprehensif guna menunjang perekonomian yang lebih baik untuk kepentingan nasional.

Usaha Mikro Kecil (UMK) juga berlaku di dalam desa. Usaha Mikro Kecil (UMK) ini merupakan suatu usaha yang penting di dalam pembangunan desa. UMK memiliki peran yang sangat strategis dalam mendukung pembangunan ekonomi desa, bahkan ekonomi nasional karena dalam kegiatan UMK ini dapat menyerap tenaga kerja dari masyarakat desa itu sendiri, serta kegiatan UMK dapat berperan dalam pendistribusian hasil-hasil pembangunan desa. Selain itu, kegiatan UMK dapat membantu memanfaatkan potensi-potensi yang ada di desa tersebut, mulai dari sumber daya alamnya, serta potensi sumber daya manusianya (Astria Yuli, Amanda Raissa, Tomy Michael, 2020). 
Perhitungan harga pokok produksi sangat penting bagi setiap perusahaan ataupun usaha mikro kecil (UMK). Harga pokok produksi merupakan dasar dalam penentuan laba perusahaan dan juga sebagai pedoman dalam menentukan harga jual produk. Oleh karena pentingnya perhitungan harga pokok produksi maka setiap perusahaan diharapkan dapat menghitung harga pokok produksi secara akurat berdasarkan prosedur akuntansi yang semestinya. Banyak usaha mikro kecil yang berada di Desa tidak menerapkan perhitungan harga pokok produksi dalam usahanya. Maka dari itu, ketidaktahuan mengenai penentuan harga pokok produksi ini yang mendorong untuk melakukan kegiatan pengabdian ini bagi Desa (Wulandari et al. 2016). Biaya bersama merupakan biaya proses produksi yang menghasilkan berbagai produk secara bersama, sampai pada titik split-off. Titik split-off merupakan titik dimana produk bersama menjadi dapat diidentifikasikan secara terpisah. Masalah utama yang dihadapi dalam proses produksi yang mengandung unsur biaya bersama adalah menghitung alokasi biaya bersama ke tiap produk yang dihasilkan.

Terdapat berbagai macam metode untuk menghitung besamya alokasi biaya bersama, salah satu metode yang paling lazim digunakan menürut (Mulyadi 2016) adalah metode Nilai jual relatif atau biasa disebut dengan metode harga pasar. Metode harga pasar didasarkan atas harga jual dari suatu produk yang merupakan perwujudan dari biaya-biaya yang dikeluarkan dalam mengolah produk tersebut.

Data yang didapatkan di desa Botubarani kecamatan Kabila Bone Kabupaten Bone Bolango Provinsi Gorontalo, terdapat 91 UMK yang melakukan kegiatan bisnis untuk menopang perekonomian demi mencapai kesejahteraan bersama.

Berdasarkan fenomena diatas, tim pengabdi melakukan kegiatan pengabdian kepada masyarakat dengan judul "Penentuan Harga Pokok Produk Bersama bagi Usaha Kecil Menengah". Pengabdian ini dilakukan di Desa Botubarani Kecamatan Kabila Bone Kabupaten Bone Bolango Provinsi Gorontalo.

\section{Metode}

Khalayak sasaran dalam kegiatan pengabdian adalah 91 UMK di pesisir yang termasuk kawasan Teluk Tomini yang berada di Desa Botubarani Kecamatan Kabila Bone Kabupaten Bone Bolango Provinsi Gorontalo. Karena masih dalam kondisi pandemi ini pengabdi membatasi jumlah peserta yakni hanya berkisar 20-25 peserta pelatihan dari UMK disesuaikan dengan kondisi ruangan dengan tetap menerapkan protokol kesehatan $3 \mathrm{M}$.

Metode ceramah digunakan oleh pemateri untuk menjelaskan materi yang berkaitan dengan pelatihan penentuan Harga Pokok Produk Bersama Nilai Jual Relatif untuk tiap produk yang dihasilkan UMK; 2) Metode diskusi dan sharing digunakan untuk memperdalam materi bahasan baik bentuk tanya jawab secara perorangan maupun perwakilan peserta.3) Praktik melakukan perhitungan penentuan harga pokok produk bersama bagi seluruh peserta ataupun secara perwakilan peserta.

\section{Hasil}

Bagian ini mengemukakan gambaran umum lokasi dan data yang diperoleh selama pelaksanaan kegiatan pengabdian pada masyarakat (PPM). Kegiatan ini dilakukan dengan menggunakan metode ceramah, diskusi share dan tanya jawab. Kegiatan ini merupakan 
pengabdian dalam rangka menumbuhkan minat dan kesadaran para peserta yakni masyarakat yang berada di Desa Borubarani Kecamatan Kabila Bone Kabupaten Bone Bolango Provinsi Gorontalo dalam menentukan harga pokok produk bersama pada UMK di Desa Botubarani.

Peserta pelatihan pada tahap awal (sesi I), diberikan materi tentang bagaimana menentukan harga pokok produk bersama. Peserta pada tahap ke dua (sesi II) diberikan materi tentang Cara perhitungan harga pokok produk bersama. Setelah itu para peserta diajak berdialog dengan tanya jawab menyangkut materi yang disampaikan. Sedangkan hasil evaluasi yang telah dilakukan untuk mengukur tingkat keberhasilan program kegiatan pengabdian ini, dapat dijabarkan sebagai berikut:

a. Pengetahuan serta minat dari para peserta yakni masyarakat di Desa Botubarani

b. Tingkat pengetahuan dan pemahaman para peserta yakni masyarakat diukur dengan partisipasi yang berkembang dalam tanya jawab.

Berdasarkan data di lapangan Nampak bahwa para peserta kegiatan pelatihan perlu pendampingan/pembinaan lebih lanjut dalam menghitung penentuan Harga Pokok Produk Bersama Produk dan kegiatan ini dilihat dari keseriusan peserta dengan mengajukan pertanyaan selesai penyampaian materi dan di barengi diskusi masalah terkait materi.

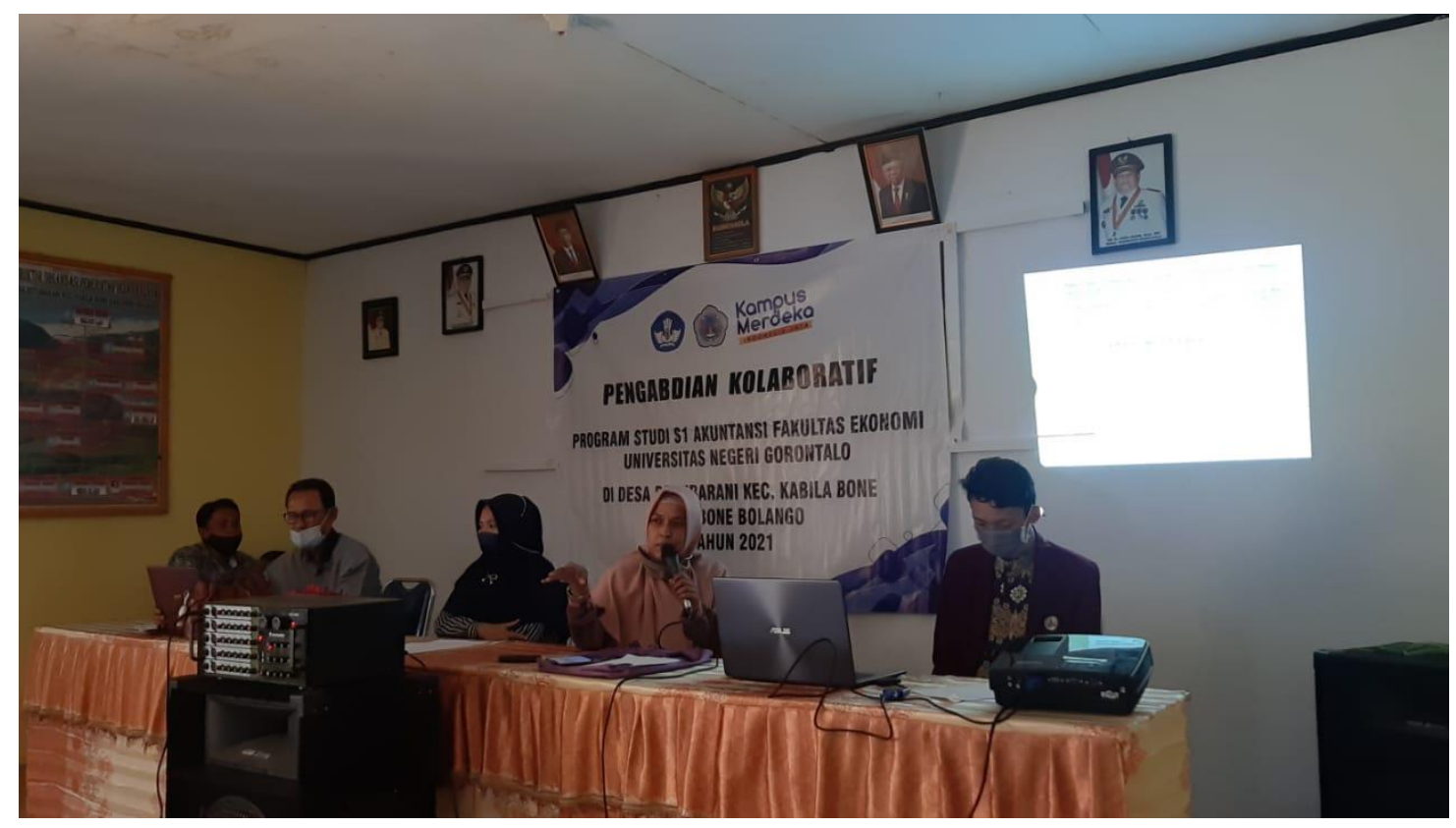

Gambar 1: Pemateri Pengabdian 


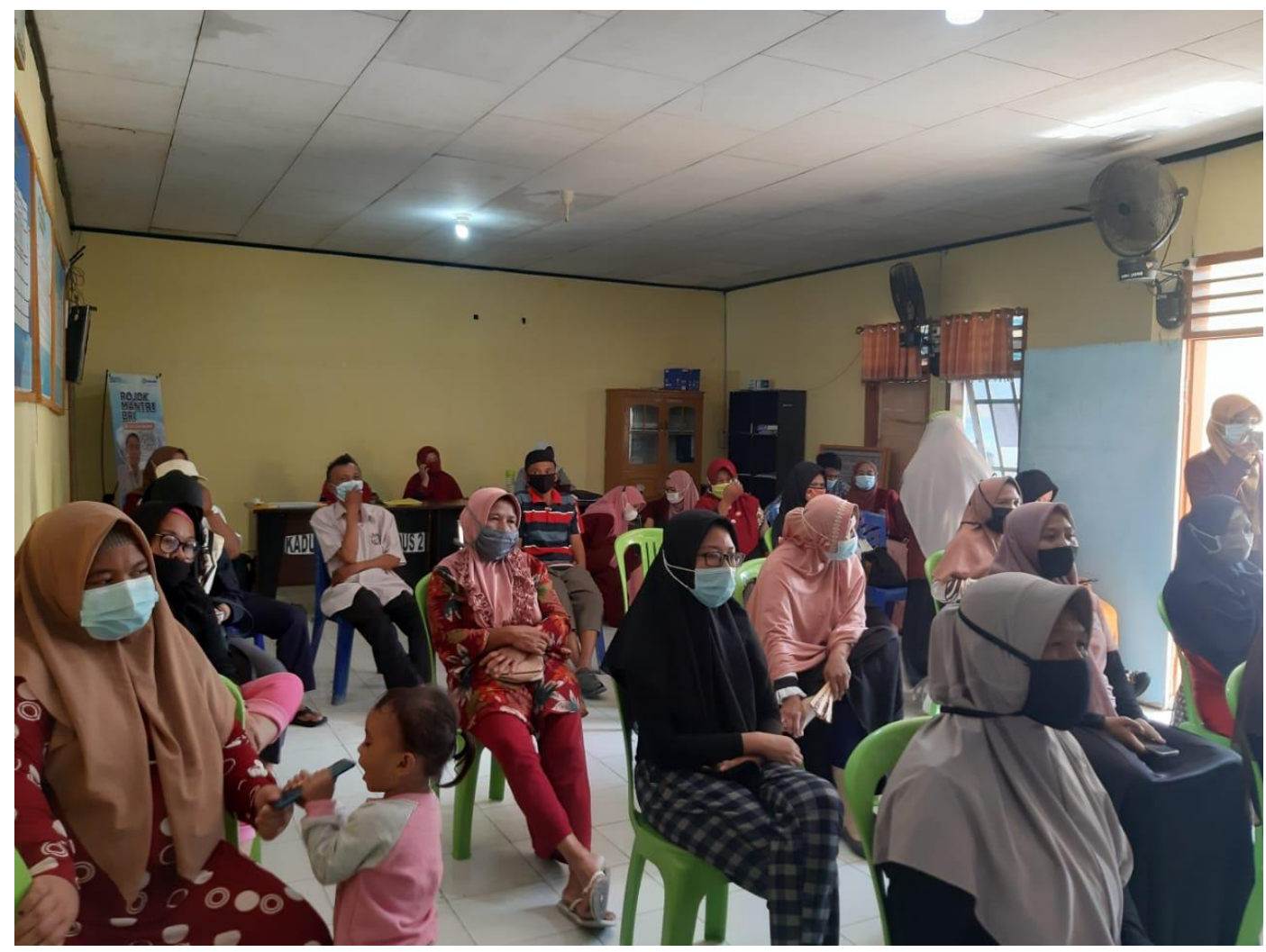

Gambar 2: Peserta Pengabdian

\section{Diskusi}

Di Indonesia Usaha Mikro dan Kecil (UMK) yang berkembang merupakan salah satu faktor yang mendukung pembangunan ekonomi nasional. Hal ini karena UMK mampu mengurangi masalah kesenjangan pendapatan, mampu membantu pengentasan kemiskinan, serta dapat membuka lahan pekerjaan baru. UMK yang maju dapat berkontribusi secara signifikan meningkatkan perekonomian daerah, (Munizu 2010). Namun, semua keberhasilan tersebut memiliki titik kelemahan seperti kurangnya permodalan, kurangnya kemampuan manajemen usaha, dan minimnya ketrampilan serta terbatasnya pemasaran dimana hal ini menjadi tugas Pemerintah. (Suci et al. 2017).

Dengan membandingkan biaya produk yang sebenarnya dengan biaya produk standar, biaya produk dapat mencerminkan apakah perusahaan tersebut berproduksi secara efektif. Dalam suatu perusahaan industri yang menghasilkan beberapa produk atau lebih dalam satu proses atau serangkaian proses, penentuan harga pokok barang sangat rumit. Hal terpenting dalam menentukan harga pokok produksi melalui proses gabungan adalah bagaimana mengalokasikan biaya produksi termasuk biaya bahan baku langsung, biaya tenaga kerja langsung dan biaya tidak langsung pabrik ke produk yang dihasilkan di titik pemisah atau split off). Dalam akuntansi biaya, produk bersama dan produk sampingan mengacu pada produk yang dihasilkan melalui serangkaian proses produksi dari awal hingga produk akhir, (Fauziyyah, Irwansyah, and Ersyafdi 1967).

Pemberian sosialisasi dan pelatihan serta pendampingan secara berkelanjutan disertai support dari pemerintah daerah setempat dapat memberikan pengembangan UMK yang positif bagi UMK di desa Botubarani mengingat terdapat 91 UMK yang tercatat di daerah pesisir kawasan Teluk Tomini ini yang melakukan kegiatan bisnis untuk menopang perekonomian 
demi mencapai kesejahteraan bersama.

\section{Kesimpulan}

Peserta yakni masyarakat di Desa Botubarani Kecamatan Kabila Bone Kabupaten Bone Bolango Provinsi Gorontalo kurang memiliki kemampuan dalam menentukan harga produk bersama, sehingga dengan adanya pengabdian ini menambah pemahaman masyarakat terkait penentuan harga pokok produk bersama. Hasil kegiatan pelatihan ini sangat bermanfaat bagi para peserta yang memiliki usaha mikro kecil agar dapat melakukan pencatatan terhadap penghasilan yang mereka produksi maupun distribusikan. Pembinaan lebih lanjut diperlukan agar hasil dari kegiatan pengabdian ini lebih membawa dampak positif ke arah perkembangan usaha lebih baik dan maju.

\section{Pengakuan/Acknowledgements}

Ucapan terima kasih yang tak terhingga disampaikan kepada LPPM Universitas Negeri Gorontalo. Pemerintah daerah desa Botubarani dan peserta yakni UMK desa Botubarani atas kesempatan, waktu, dan perhatian yang luar biasa yang diberikan kepada kami tim pengabdi dapat melaksanakan kegiatan ini dengan baik. Kedepan diharapkan kegiatan pengabdian kepada masyarakat ini terus berkelanjutan.

\section{Daftar Referensi}

Mulyadi. 2016. Akuntansi Biaya. 5th ed. edited by U. S. YKPN. Yogyakarta: UPP STIM YKPN.

Statistik, Badan Pusat. 2017. Potensi Usaha Mikro Kecil. Jakarta.

Suci, Yuli Rahmini, Sekolah Tinggi, and Ilmu Ekonomi. 2017. "Perkembangan UMKM (Usaha Mikro Kecil Menengah) Di Indonesia." Jurnal Ilmiah Fakultasi Ekonomi 6(1):51-58.

Wulandari, Indriyani Eka, Alwan Sri Kustono, Ak Ca, and Norita Citra Yuliarti. 2016. "( Analysis Determining the Cost of Production with a Full Costing Method on Small and Medium Enterprise Tape Handayani 82 Bondowoso ).” E-Jurnal Pustaka Akuntansi. 